\title{
STATUS KUALITAS AIR DI KAWASAN PARIWISATA NUSA PENIDA
}

\author{
Nyoman Sudipa $^{1 *}$, Made Sudiana Mahendra ${ }^{2)}$, Wayan Sandi Adnyana ${ }^{3)}$, Ida Bagus \\ Pujaastawa $^{4)}$ \\ ${ }^{1)}$ Fakultas Teknik, Universitas Mahendradatta \\ ${ }^{2}$ Program Studi Doktor Ilmu Lingkungan, Universitas Udayana. \\ ${ }^{3)}$ Program Studi Agroteknologi, Universitas Udayana \\ ${ }^{4)}$ Program Studi Ilmu Budaya, Universitas Udayana \\ *Email: nyoman_sudipa@yahoo.com
}

\section{ABSTRACT \\ WATER QUALITY STATUS IN NUSA PENIDA TOURISM AREA}

Environmental water quality is very influential on environmental sustainability and tourism in the Nusa Penida Tourism Area. Changes in environmental water quality are influenced by human activities in utilizing environmental resources. As a developing tourism area, Nusa Penida has a source of environmental water from springs, groundwater and has marine waters with biodiversity that become underwater paradise. The method used by analyzing water quality uses a standardized quality approach based on Bali Governor's Regulation No. 16 of 2016 concerning Environmental Quality Standards and Environmental Damage Quality Criteria and to find out the water pollution index using the approach of the Decree of the Minister of Environment No. 51 of 2004, then compared with environmental water quality using environmental water quality tests that have been carried out in the Study of Analysis Regarding the Environmental Impact of the Nusa Penida Tourism Area in 1998.Tests for the quality of sea water, well water and spring water in 2019 each showed relatively better results compared to the results of quality tests for sea water, well water and spring water in 1998. Influential parameters The index of sea water pollution, well water and spring water in Nusa Penida are turbidity parameters, free ammonia $\left(\mathrm{NH}_{3}-\mathrm{N}\right)$ dissolved residue (TDS) and total coliform, respectively.

Keywords: environment; quality; water; tourism; Nusa Penida.

\section{PENDAHULUAN}

Kelangsungan hidup pariwisata salah satunya ditentukan oleh kualitas lingkungan hidup (Soemarwoto, 2001). Kawasan Pariwisata Nusa Penida yang sedang berkembang menghasilkan limbah dan membutuhkan sumber daya air baik kuantitas maupun kualitas (Utami, 2004). Keberadaan limbah di badan air mengakibatkan penurunan kualitas lingkungan yang disebabkan oleh aktivitas manusia sehingga mengakibatkan terakumulasinya bahan organik di badan perairan (Panggabean et al., 2016). Akumulasi bahan organik dan bahan pencemar lainnya di perairan meningkatkan partikel organik dan bakteri yang mempengaruhi kualitas air. Nusa Penida sebagai kawasan konservasi perairan dan sebagai obyek wisata selam yang sangat diminati wisatawan. Ramainya aktivitas perairan laut karena aktivitas tarnsfortasi antar pulau, wisata menyelam, dan aktivitas lain di perairan meimbulkan tekanan baik secara fisik, kimia dan mikrobiologi (Laapo et all, 2009).

Analisis kualitas air di Nusa Penida dibandingkan dengan hasil Analisis kualitas air dari studi Dampak Lingkungan Kawasan Pariwisata Nusa Penida Tahun 1998 dapat memberikan gambaran perubahan kualitas lingkungan dari tahun 1998 sampai saat ini. Kualitas air di Nusa Penida memberikan 
manfaat bagi pengusaha, masyarakat dan pemerintah untuk keberlanjutan pariwisata Perubahan kualitas lingkungan dilihat dari tingkat pencemaran air, salah satu metode analisis yang dapt digunakan adalah Analisis Indeks Pencemaran (Rahmawan et al., 2017). Pencemaran melalui media air adalah penyebab munculnya wabah penyakit dan merupakan ancaman utama bagi kesehatan masyarakat (Faskas et al., 2020). Mengetahui kualitas lingkungan, khususnya tingkat pencemaran air sangat penting sebagai dasar pertimbangan arah kebijakan untuk penyusunan program pengawasan dan pemulihan terhadap komponen lingkungan yang mengalami penurunan kualitas sebagai bagian dari manajemen risiko (Sudipa ${ }_{\mathrm{a}}$ et al, 2006).

\section{METODOLOGI}

Perubahan kualitas air tanah, air sumur, kualitas mata air dan kualitas air laut yang diakibatkan oleh perkembangan pariwisata diketahui dengan membandingkan tingkat pencemaran air pada tahun 1998 dan saat ini. Tingkat pencemaran dihitung dengan Indeks Pencemaran. Data kualitas air tahun 1998 menggunakan data kualitas air dari hasil studi Dampak Lingkungan Kawasan Pariwisata Nusa Penida Tahun 1998 (Badan Perencanaan Pembangunan Daerah Provinsi Bali, 1998/1999). Data kualitas air saat ini diperoleh melalui pemeriksaan parameter kualitas air dari sampel air. Pengambilan sampel air tanah/sumur dan sungai dilakukan pada 6 titik yaitu sumur di Jungutbatu, mata air Penida, sumur Dusun Tanah Bias Desa Ped, air PDAM di Banjar Buyuk Kutampi, sumur di Batununggul, dan sumur di Lembongan. Sampel air laut diambil pada 6 titik lokasi yaitu air laut di Jungutbatu, air laut Toyapakeh, air laut Tanah Bias Ped, air laut Buyuk Kutampi, air laut Sampalan dan air laut Suana.

Kriteria baku mutu yang dipergunakan untuk menganalisis kualitas air tanah, air sumur untuk syarat kualitas air minum dan air laut untuk syarat kepentingan pariwisata menggunakan Peraturan Gubernur Bali Nomor 16 Tahun 2016 terlihat pada Tabel 1 dan Tabel 2.

Tabel 1. Analisis Kualitas Air Tanah, Air Sumur dan Mata Air

\begin{tabular}{|l|l|l|c|c|c|c|}
\hline No & \multicolumn{1}{|c|}{ Parameter } & Satuan & \multicolumn{3}{c|}{ PerGub No. 16 Tahun 2016 } \\
\hline & & & Kls I & KIs II & Kls III & Kls IV \\
\hline A. & FISIKA & & & & & \\
\hline 1 & Suhu & ${ }^{\circ} \mathrm{C}$ & Dev. 3 & Dev. 3 & Dev. 3 & Dev. 5 \\
\hline 2 & TDS & ppm & 1000 & 1000 & 1000 & 2000 \\
\hline B. & KIMIA & & & & & \\
\hline 1 & $\mathrm{pH}$ & $\mathrm{ppm}$ & $6-9$ & $6-9$ & $6-9$ & $5-9$ \\
\hline 2 & $\mathrm{Ba}$ & $\mathrm{ppm}$ & 1 & $(-)$ & $(-)$ & $(-)$ \\
\hline 3 & $\mathrm{Fe}$ & $\mathrm{ppm}$ & 0,3 & $(-)$ & $(-)$ & $(-)$ \\
\hline 4 & $\mathrm{Mn}$ & $\mathrm{ppm}$ & 0,1 & $(-)$ & $(-)$ & $(-)$ \\
\hline 5 & $\mathrm{Cu}$ & $\mathrm{ppm}$ & 0,02 & 0,02 & 0,02 & 0,02 \\
\hline 6 & $\mathrm{Zn}$ & $\mathrm{ppm}$ & 0,05 & 0,05 & 0,05 & 2 \\
\hline 7 & $\mathrm{Cr}$ & $\mathrm{ppm}$ & 0,05 & 0,05 & 0,05 & 1 \\
\hline 8 & $\mathrm{Cd}$ & $\mathrm{ppm}$ & 0,01 & 0,01 & 0,01 & 0,01 \\
\hline 9 & $\mathrm{Hg}$ & $\mathrm{ppm}$ & 0,001 & 0,002 & 0,002 & 0,005 \\
\hline 10 & $\mathrm{~Pb}$ & $\mathrm{ppm}$ & 0,03 & 0,03 & 0,03 & 1 \\
\hline 11 & As & $\mathrm{ppm}$ & 0,05 & 1 & 1 & 1 \\
\hline 12 & $\mathrm{Se}$ & $\mathrm{ppm}$ & 0,01 & 0,05 & 0,05 & 0,05 \\
\hline 13 & Amoniak bebas $\left(\mathrm{NH}_{3}-\mathrm{N}\right)$ & $\mathrm{ppm}$ & 0,5 & $(-)$ & $(-)$ & $(-)$ \\
\hline 14 & Nitrat $\left(\mathrm{NO}_{3}-\mathrm{N}\right)$ & $\mathrm{ppm}$ & 10 & 10 & 20 & 20 \\
\hline 15 & Nitrit $\left(\mathrm{NO}_{2}-\mathrm{N}\right)$ & $\mathrm{ppm}$ & 0,06 & 0,06 & 0,06 & $(-)$ \\
\hline 16 & Deterjen & $\mathrm{ppm}$ & 0,2 & 0,2 & 1 & 5 \\
\hline
\end{tabular}




\begin{tabular}{|l|l|c|c|c|c|c|}
\hline No & \multicolumn{1}{|c|}{ Parameter } & Satuan & \multicolumn{3}{c|}{ PerGub No. 16 Tahun 2016 } \\
\hline & & & Kls I & Kls II & Kls III & Kls IV \\
\hline C. & MIKROBIOLOGI & & & & & \\
\hline 1 & Total Coliform & MPN/100 ml & 1000 & 5000 & 10000 & 10000 \\
\hline 2 & Faecal Coliform & MPN/100 ml & 100 & 1000 & 2000 & 2000 \\
\hline
\end{tabular}

Sumber : Pergub. Bali No. 16 Tahun 2016

Indeks pencemaran dihitung dengan (Ci/ Lij)M: Ci/Lij Maksimum persamaan sebagai berikut:

(Ci/ Lij)R : Ci/Lij Rata-rata

$\operatorname{PIj}=\sqrt{\frac{\left(\frac{C i}{L i j}\right)_{M}^{2}+\left(\frac{C i}{L i j}\right)_{R}^{2}}{2}}$

Keterangan:

Li: Kualitas air peruntukan air (j)

Ci: Kualitas air hasil survei
Satus mutu air dinyatakan sebagai berikut: 1. $0 \leq \mathrm{PIj} \leq 1,0$ : Sesuai baku mutu (kondisi baik)

2. $1,0<\mathrm{PIj}<5,0$ : Air tercemar ringan

3. $5,0<\mathrm{PIj} \leq 10:$ Air tercemar sedang

4. $\mathrm{PIj}>10:$ Tercemar berat

Tabel 2. Parameter Analisis Kualitas Air Laut

\begin{tabular}{|c|c|c|c|}
\hline No & Parameter & Satuan & PerGub No. 16 Tahun 2016 \\
\hline A. & FISIKA & & \\
\hline 1 & Suhu & ${ }^{0} \mathrm{C}$ & $26-30$ \\
\hline 2 & Bau & & Alami \\
\hline 3 & Kekeruhan & ppm SiO2 & $<10$ \\
\hline 4 & Residu terlarut (TDS) & $\mathrm{ppm}$ & $\leq 20$ \\
\hline B. & KIMIA & & \\
\hline 1 & $\mathrm{pH}$ & & $6,5-8$ \\
\hline 2 & $\mathrm{Cu}$ & $\mathrm{ppm}$ & 0,008 \\
\hline 3 & $\mathrm{Zn}$ & ppm & 0,002 \\
\hline 4 & $\mathrm{Cr}$ & ppm & 0,00004 \\
\hline 5 & $\mathrm{Cd}$ & $\mathrm{ppm}$ & 0,00002 \\
\hline 6 & $\mathrm{Hg}$ & $\mathrm{ppm}$ & 0,0001 \\
\hline 7 & $\mathrm{~Pb}$ & $\mathrm{ppm}$ & 0,00002 \\
\hline 8 & As & $\mathrm{ppm}$ & 0,0026 \\
\hline 9 & $\mathrm{Se}$ & $\mathrm{ppm}$ & 0,00045 \\
\hline 10 & Amoniak bebas $\left(\mathrm{NH}_{3}-\mathrm{N}\right)$ & $\mathrm{ppm}$ & nihil \\
\hline 11 & Nitrit $\left(\mathrm{NO}_{2}-\mathrm{N}\right)$ & ppm & nihil \\
\hline 12 & Deterjen & ppm & ttd \\
\hline C. & MIKROBIOLOGI & & \\
\hline 1 & Total Coliform & MPN/100 ml & - \\
\hline 2 & Faecal Coliform & MPN/100 ml & - \\
\hline
\end{tabular}

Sumber : Pergub Bali No. 16 Tahun 2016

\section{HASIL DAN PEMBAHASAN}

Hasil analisis seluruh sampel air tanah/sumur dan sungai yaitu sumur di Jungutbatu, mata air Penida, sumur Dusun Tanah Bias Desa Ped, air PDAM di Banjar
Buyuk Kutampi, sumur di Batununggul, dan sumur di Lembongan menunjukkan bahwa mutu air dalam kondisi tercemar ringan, sedangkan sampel air laut yaitu air laut di Jungutbatu, air laut Toyapakeh, air laut Tanah Bias Ped, air laut Buyuk Kutampi, air laut Sampalan dan air laut Suana 
menunjukkan dalam kondisi tercemar ringan. Hasil uji sampel kualitas air menunjukkan bahwa terdapat 4 parameter yang mempengaruhi indeks pencemaran air yaitu kekeruhan, amoniak bebas $\left(\mathrm{NH}_{3}-\mathrm{N}\right)$, residu terlarut (TDS) dan total coliform. Untuk parameter kekeruhan, amoniak bebas $\left(\mathrm{NH}_{3-}^{-}\right.$
N) berada diatas ambang batas baku mutu pada uji kualitas air laut dan parameter residu terlarut (TDS) dan total coliform berada diatas batas baku mutu pada uji kualitas air sumur dan mata air dan air laut Adapun perbandingan keempat parameter tersebut dapat dilihat pada Gambar 1.

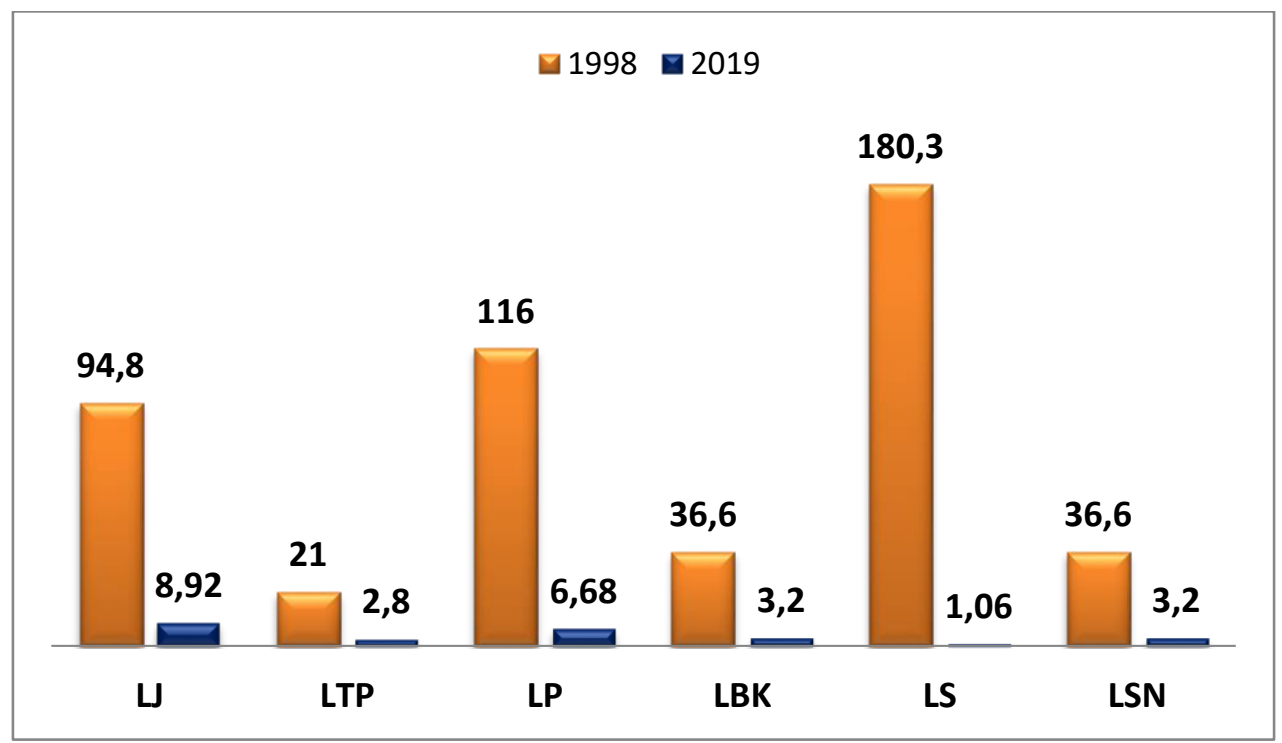

LJ = air laut Jungutbatu, LTP = air laut Toyapakeh, LP = air laut Penida, LBK = air laut Buyuk Kutampi, LS = air laut sampalan, LSN = air laut Suana

Gambar 1.

Perbandingan Parameter Kekeruhan Air Laut

Hasil Pengambilan Sampel Tahun 1998 dan 2019

Kondisi parameter fisika yaitu kekeruhan air laut di perairan Nusa Penida pada tahun 2019 relatif lebih baik dibandingkan dengan kondisi tahun 1998. Angka kekeruhan air laut kemungkinan karena adanya senayawa organik yang berasal dari aktivitas di daratan yang masuk ke laut. Pertumbuhan fitoplankton dipengaruhi karena suburnya perairan yang bisa disebabkan karena aktivitas pertanian di daratan seperti penggunaan pupuk. Sebelum tahun 1995 kondisi lahan di Nusa Penida cukup kritis karena kurangnya aktivitas penghijauan sehingga pada saat musim hujan run off air membawa material lumpur masuk ke laut yang menyebabkan meningkatnya kekeruhan air laut.

Pasca tahun 1995 dengan kesadaran sendiri masyarakat, disamping meningkatnya nilai ekonomis kayu terutama jati, mahoni, intaran dan tanaman perdu untuk kebutuhan pakan ternak sapi serta ditunjang oleh program pemerintah berupa gerakan rehabilitasi hutan dan lahan (Gerhan), dilakukan penghijauan secara besar-besaran dari tahun ke tahun, bahkan lahan produktif untuk tanaman pangan banyak beralih fungsi menjadi hutan rakyat baik di wilayah perbukitan maupun di wilayah pesisir. Limpasan penggunaan pupuk untuk tanaman pangan saat musim hujan diserap oleh tanaman hutan sehingga limpasan pupuk yang masuk ke perairan menjadi berkurang. Limpasan pupuk yang masuk ke perairan menyebabkan perairan menjadi subur dapat meningkatkan pertumbuhan fitoplankton. Konsentrasi pupuk yang tinggi dapat meningkatkan kepadatan sel dan klorofil yang tinggi akan membuat warna hijau dari fitoplankton di perairan (Octhreeani et al., 2014). Faktor lain yang menyebab turunnya angka kekeruhan air laut disebabkan karena 
berkurangnya sidementasi, erosi, partikel koloid dan air buangan dari daratan terutama saat hujan jauh berkurang. Hal ini bisa dilihat sebelum tahun 2000, dimana saat puncak musim hujan air bah mengalir dengan deras menuju ke laut dengan warna yang pekat yang banyak mengandung partikel koloid. Setelah tahun 2005 sampai sekarang intensitas air bah jauh berkurang.
Untuk menjaga kualitas perairan, perlu dilakukan gerakan bersama antara pemerintah, masyarakat, pengusaha, lembaga swadaya masyarakat dan para penggiat lingkungan untuk melakukan menjaga kondisi lingkungan di wilayah darat dengan menjaga hutan, melakukan penghijauan secara berkelanjutan dan merapkan pertanian ramah lingkungan atau pertanian organik.

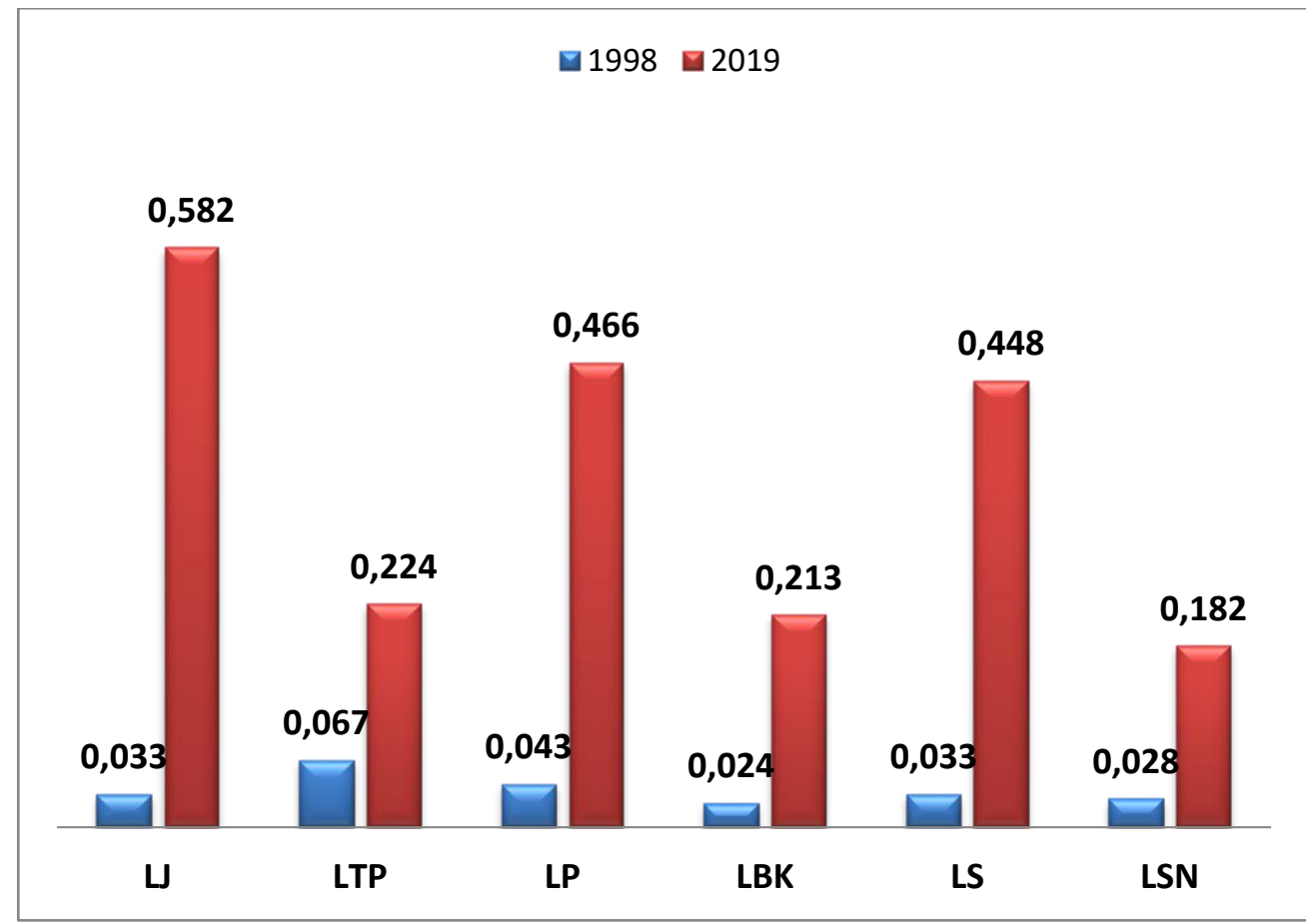

LJ = air laut Jungutbatu, LTP = air laut Toyapakeh, LP = air laut Penida, $\mathrm{LBK}=$ air laut Buyuk Kutampi, LS = air laut sampalan, LSN = air laut Suana

Gambar 2.

Perbandingan Parameter Amoniak bebas $\left(\mathrm{NH}_{3}-\mathrm{N}\right)$ Air Laut Hasil Pengambilan Sampel Tahun 1998 dan 2019

Tingginya konsentrasi Amoniak bebas $\left(\mathrm{NH}_{3}-\mathrm{N}\right)$ di perairan Nusa Penida kemungkinan berasal dari limbah rumah tangga dan dari limbah kamar mandi (urin) karena sebaran permukiman penduduk Nusa Penida berada di daerah pantai. Amonikan bebas juga berasal dari metabolisme hewan yang berada di daratan yang diurai oleh bakteri melalui proses dekomposisi, atau mungkin dari pupuk pertanian, limbah dari aktivitas pariwisata yang masuk ke perairan. Makin tumbuhnya Pariwisata Nusa Penida menyebabkan makin meningkatnya konsumsi domestik dan konsumsi pariwisata yang tentu menghasilkan limbah yang berpotensi mencemari perairan. Menurut Effendi (2003) secara alami ammonia yang ada di air laut merupakan dekomposisi bahan organi oleh bakteri yang berasal dari hasil metabolisme hewan. Tingginya Amoniak bebas $\left(\mathrm{NH}_{3}-\mathrm{N}\right)$ di perairan Nusa Penida diperkirakan dari daratan yang berasal dari ativitas penduduk berupa limbah baik yang berasal dari manusia maupun hewan dalam bentuk urin.

Untuk mengurangi kadar ammonia di perairan Nusa Penida perlu dilakukan perubahan perilaku seperti menjaga lingkungan bersih dan sehat, menerapkan sistem sanitasi yang baik, membuat 
pengolahan limbah bagi para pemilik Jika limbah tidak dikelola dengan baik, maka akomodasi, pertanian ramah lingkungan dan bisa menimbulkan dampak terhadap perairan melakukan pengolahan sampah dengan baik. (Sudipa ${ }_{\mathrm{b}}$ et al., 2020)

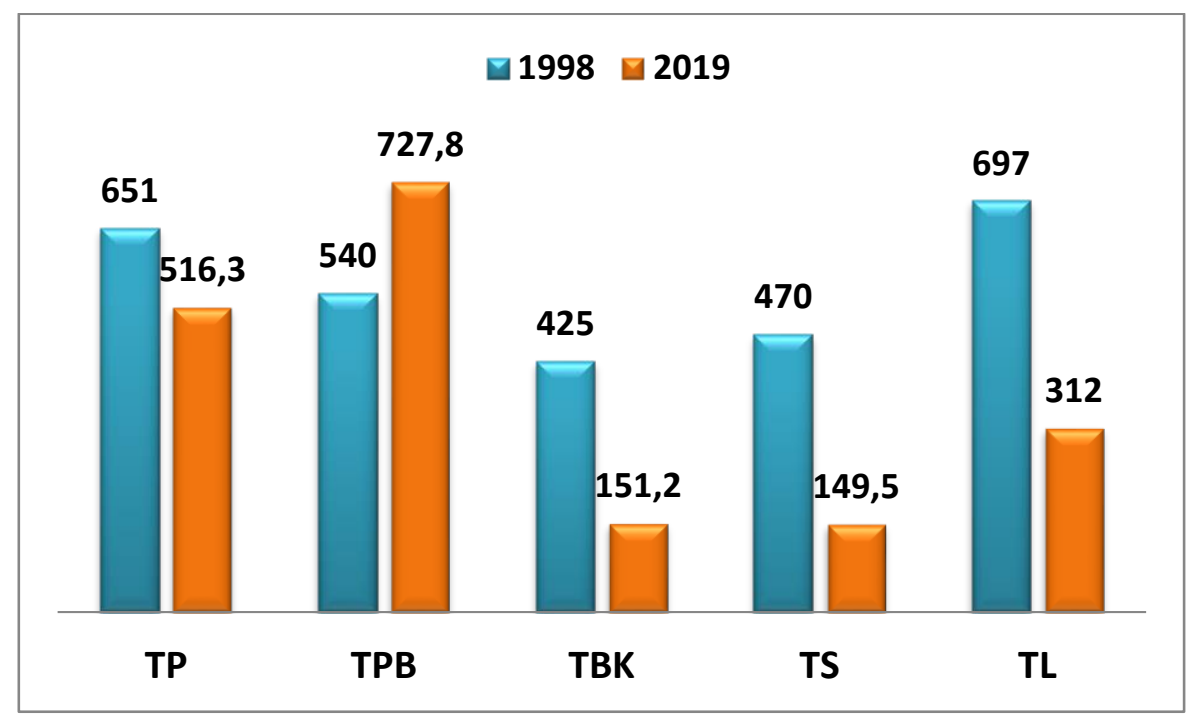

TP = mata air Penida, TPB = sumur Tanah Bias, TBK = Air PDAM di Buyuk Kutampi, TS = sumur Sampalan Batununggul, TL = sumur Lembongan

Gambar 3.

Perbandingan Parameter Residu Terlarut (TDS) Air Sumur dan Mata Air Hasil Pengambilan Sampel Tahun 1998 dan 2019

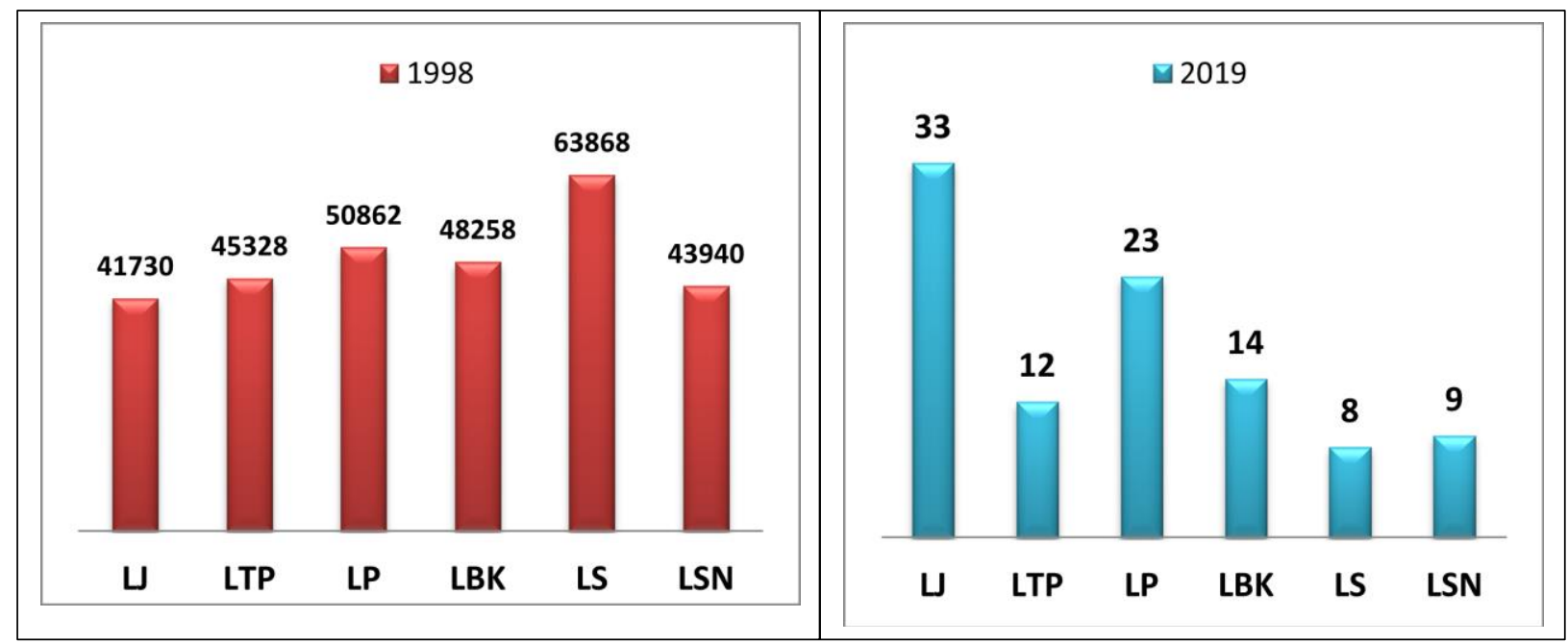

LJ = air laut Jungutbatu, LTP = air laut Toyapakeh, LP = air laut Penida, LBK = air laut Buyuk Kutampi, LS = air laut sampalan, LSN = air laut Suana

Gambar 4.

Perbandingan Parameter Residu Terlarut (TDS) Air Laut Hasil Pengambilan Sampel Tahun 1998 dan 2019

Kondisi sumur, mata air dan perairan Nusa Penida Tahun 2019 relatif lebih baik dibandingkan dengan kondisi tahun 1998, terutama dari sisi kualitas air, khususnya parameter fisika yaitu residu terlarut (TDS) yang jauh menurun terutama residu terlarut (TDS) air laut. Dugaan sementara menurunnya residu terlarut (TDS) disebabkan berubahnya perilaku masyarakat dalam mengelola lingkungan terutama 
berhasilnya penghijauan yang dilakukan secara besar-besaran mulai tahun pasca tahun 1995. Perubahan terlihat mulai tahun 2005, dimana sebelum tahun 2005, jika terjadi hujan yang cukup deras akan terjadi aliran air bah yang run off melalui sungai-sungai mati menuju ke laut sangat besar, tetapi diatas tahun 2005 aliran air bah menjadi sangat berkurang karena pohon-pohon penghijauan secara aktif mampu menyerap dan menahan air hujan dan adanya pembangunan bronjong-bronjong penahan tanah dan air di beberapa areal sungai mati mampu mengurangi run off air yang mengalir ke laut. Disamping itu kesadaran terhadap penanganan sampah dan pembuangan polutan serta berkurangnya aktivitas budidaya rumput laut di Nusa Penida.
Kondisi paramater biologi yaitu total coliform pada Tahun 2019 relatif lebih baik dibandingkan dengan kondisi tahun 1998. Tingginya angka total coliform terutama di lokasi sumur dan mata air disebabkan sumur dan mata air fasilitas yang sangat vital bagi masyarakat Nusa Penida sebelum air PDAM masuk ke rumah-rumah penduduk. Sumur dan mata air dipergunakan sebagai fasilitas mandi, cuci dan kakus bagi sebagian masyarakat dan tempat memandikan dan minum ternak khususnya sapi. Masih tingginya total coliform di sumur Banjar Tanah Bias Ped karena masih dipergunakan sebagai tempat memandikan dan minum ternak sampai saat ini. Kondisi sanitasi masyarakat yang buruk pasca tahun 1998 menyebabkan tingginya total coliform hasil pengambilan sampel pada tahun 1998 .

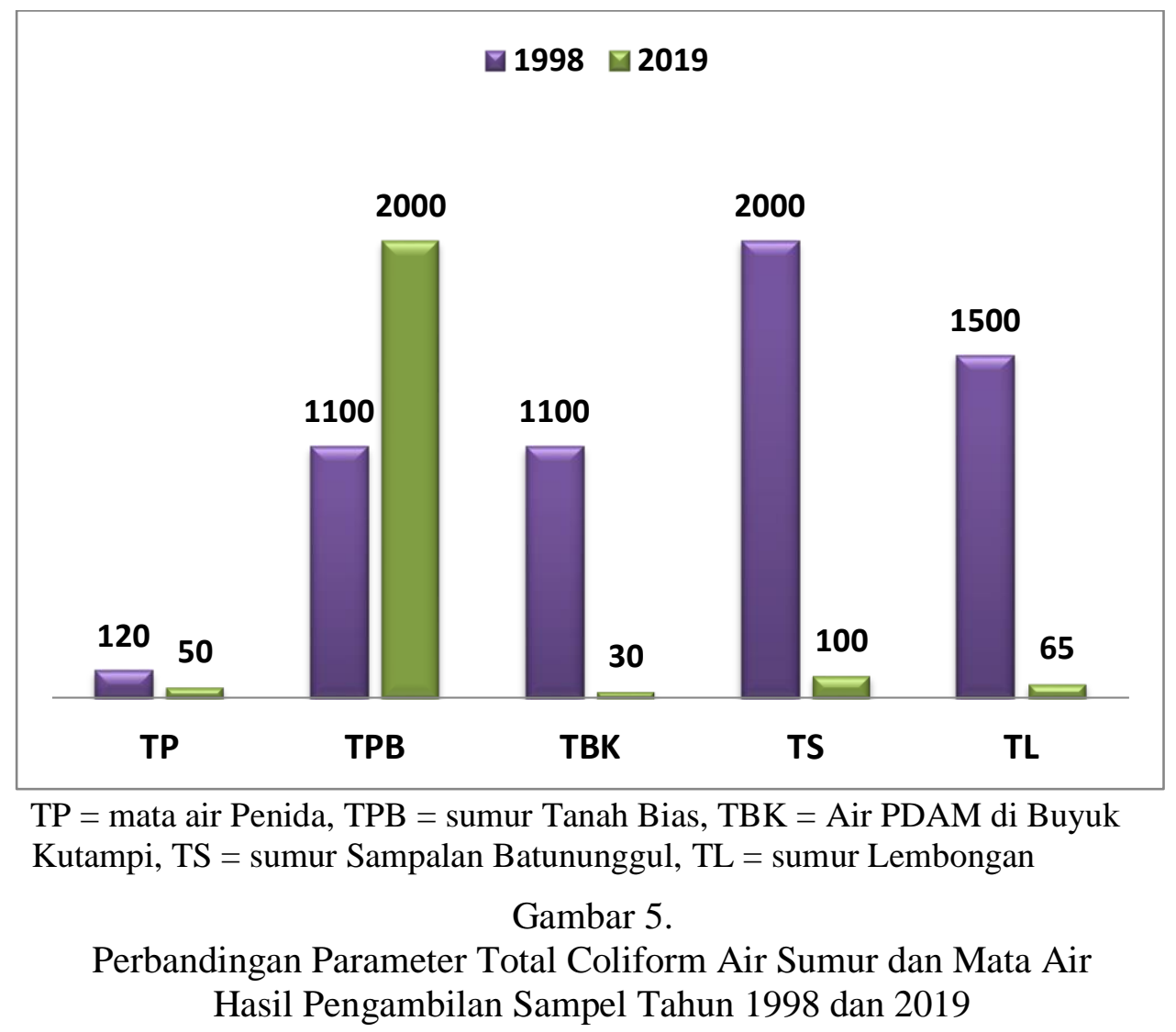

Meningkatnya kesadaran perilaku hidup bersih dan sehat terutama kesadaran membangun fasilitas buang air di kalangan masyarakat dalam 10 tahun terakhir menekan total coliform masuk ke mata air dan laut. Sebelum tahun 2008 masyarakat jarang membangun fasilitas buang air karena ketersediaan air yang terbatas dan pasca masuknya air ke rumah-rumah yang difasilitasi oleh PDAM kesadaran membangun fasilitas buang air meningkat pesat. Kampanye sanitasi sehat dari 
pemerintah serta di dukung oleh air PDAM yang sudah masuk ke beberapa desa di Nusa Penida meningkatkan pembangunan sarana sanitasi oleh penduduk. Fasilitas pembangunan bedah rumah yang menyatu dengan sarana sanitasi mendorong perilaku hidup bersih dan sehat, sehingga hasil pengambilan sampel tahun 2019 kondisi paramater biologi yaitu total coliform realatif lebih baik.

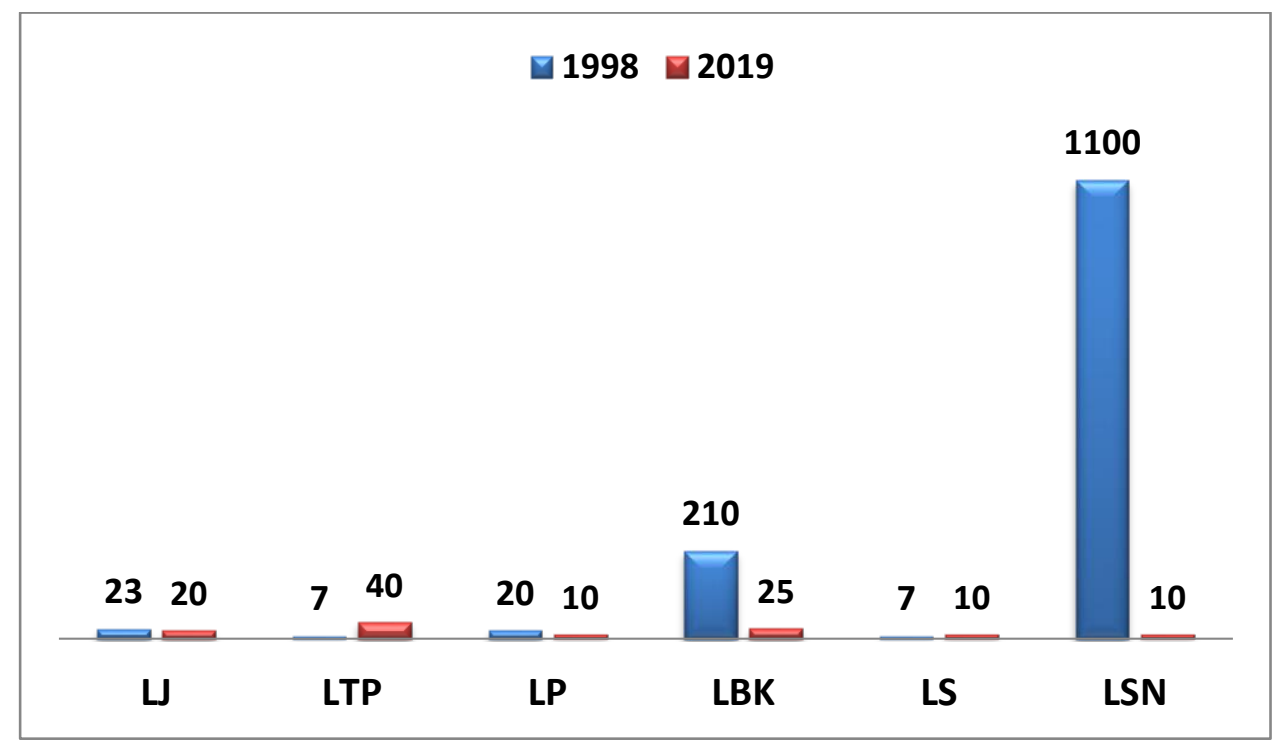

LJ = air laut Jungutbatu, LTP = air laut Toyapakeh, LP = air laut Penida, LBK = air laut Buyuk Kutampi, LS = air laut sampalan, LSN = air laut Suana

Gambar 6.

Perbandingan Parameter Total Coliform Air Laut Hasil Pengambilan Sampel Tahun 1998 dan 2018

\section{SIMPULAN}

Hasil uji kualitas air sumur di Jungutbatu, mata air Penida, sumur Dusun Tanah Bias Desa Ped, air PDAM di Banjar Buyuk Kutampi, sumur di Batununggul, dan sumur di Lembongan menunjukkan dalam kondisi tercemar ringan, sedangkan sampel air laut yaitu air laut di Jungutbatu, air laut Toyapakeh, air laut Tanah Bias Ped, air laut Buyuk Kutampi, air laut Sampalan dan air laut Suana menunjukkan dalam kondisi tercemar ringan. Uji kualitas air sumur dan mata air dan air sumur pada tahun 2019 masing-masing menunjukkan hasil yang relatif lebih baik dibandingkan dengan hasil uji kualitas air laut, air sumur dan mata air tahun 1998. Parameter yang berpengaruh terhadap indek pencemaran air laut, air sumur dan mata air di Nusa Penida masingmasing adalah parameter kekeruhan, amoniak bebas $\left(\mathrm{NH}_{3}-\mathrm{N}\right)$ residu terlarut (TDS) dan total coliform.

\section{DAFTAR PUSTAKA}

Badan Perencanaan Pembangunan Daerah Provinsi Bali. 1988. Studi Analisis Mengenai Dampak Lingkungan Kawasan Pariwisata Nusa Penida Tahun. Denpasar Bali

Effendi, H. 2003. Telaah Kualitas Air bagi Pengelolaan Sumberdaya dan Lingkungan Perairan. Cetakan Kelima. Yogjakarta: Kanisius. p 1417. 
Kata Farkas,. David I. Walker., Evelien M. Adriaenssens ., James E. McDonald., Luke S. Hillary a., Shelagh K. Malham., Davey L. Jones. 2020. Viral indicators for tracking domestic wastewater contamination in the aquatic environment: Elsivaer. P 119.

Keputusan Menteri Negara Lingkungan Hidup Nomor 51 Tahun 2004.

Laapo, A., Fahrudin., A., Bengen. D. G., Damar, A. 2009. Pengaruh Aktivitas Wisata Bahari terhadap Kualitas Perairan Laut di Kawasan Wisata Gugus Pulau Togean; Ilmu Kelautan: 14 (4): 215-221

Octhreeani, G. A., Supriharyono., Soedarsono, P. 2014. Pengaruh Perbedaan Jenis Pupuk Terhadap Pertumbuhan Nannochloropsis SP. Dilihat Dari Kepadatan Sel dan Klorofil A Pada Skala Semi Massal; Diponegoro Journal of Maquares management of Aquatic Resources: 3 (2): 102-108.

Panggabean, T. K., Sasanti. A. D., Yulisman. 2016. Kualitas Air, Kelangsungan Hidup, Pertumbuhan, dan Efisiensi Pakan Ikan Nila yang diberi Pupuk Hayati Cair pada Air Media
Pemeliharaan; Jurnal Akuakultur Rawa Indonesia: 4 (1) : 67-79

Peraturan Gubernur Bali No. 16 Tahun 2016.

Rahmawan, G. A., Gemilang, W. A. 2017. Status Baku Mutu Air Laut Perairan Teluk Ambon Luar untuk Wisata Bahari Kapal Tenggelam SS Aqualila; Enviro Scienteae; 13 (2): 139-149

Soemarwoto, O. 2001. Ekologi, Lingkungan Hidup, dan Pembangunan. Djambatan: Jakarta. p 30-39.

Sudipa $_{\mathrm{a}}$, N., Mahendra, M. S., Sudana, I. B. 2006. Studi Kualitas Hasil Pengolahan Air Limbah- Kasus Salah Satu Hotel Berbintang di Bali. Jurnal Ecotrophic: 3 (2): 1-7.

Sudipa $a$, N., Mahendra, M. S., Adnyana, W. S., \& Pujaastawa, I. B. 2020. Tourism Impact on the Environment in Nusa Penida Tourism Area. Journal Inveronmental Management and Tourism, XI (41), 113-124

Utami, N.M.N. 2004. Dampak Industri Pariwisata Terhadap Kualitas Air Tanah di Kuta, Bali, Disertasi. Program Studi Ilmu Lingkungan Pascasarjana, Universitas Indonesia. 